\title{
Role of Digital Technology in Achieving the Sustainable Development Goals: Focus on the Efforts of the International Community
}

\section{Abstract}

In the international community, digital technology is considered as the means of achieving the Sustainable Development Goals (SDGs) and effectively implementing development cooperation projects. Development cooperation activities are conducted in the field of digital technology in various forms by the major donors, namely the US, the UK, Germany, France, and Japan, who have been emphasizing on the importance of digital technology in development cooperation. These activities include the development of SDG mapping tool by the International Telecommunication Union, the establishment

* Corresponding author: Associate Fellow, Korea Information Society Development Institute / shyoo@kisdi.re.kr * Co-author: Researcher, Korea Information Society Development Institute / youngms@kisdi.re.kr

(c) Copyright Korea International Cooperation Agency. This is an Open-Access article distributed under the terms of the Creative Commons Attribution Non-Commercial License (http://creativecommons.org/licenses/by-nc/4.0/) which permits unrestricted non-commercial use, distribution, and reproduction in any medium, provided the original work is properly cited. 
of World Bank's Digital Development Cooperation System, and the announcement of the Digital Agenda 2030 by the Asian Development Bank. To improve the effectiveness of the development cooperation projects, cooperation in high-performing sectors should be further strengthened, considering the correlation between digital technology and SDGs. It is also necessary to support data-driven digital solutions and improve the understanding of the digital value chain.

Key words: Sustainable Development Goals (SDGs), Development Cooperation, International Organizations, Digital Technology, Information and Communications Technology (ICT) 


\section{INTRODUCTION}

The world is currently underscoring the importance of digital technology more than ever amid the pandemic crisis of the Coronavirus disease 2019 (COVID-19). According to the Organization for Economic Cooperation and Development (OECD), the demand for communication networks has increased significantly since the outbreak of COVID-19, and the consumption of content and application services has also surged. In the context of the COVID-19 pandemic, the importance of digital technology is being emphasized to establish a disease monitoring and response system and to raise public awareness.

However, as digital transformation accelerates due to the spread of COVID-19, the digital divide between and within countries is being reinforced. Digital transformation is being demanded across all aspects of social life, but digital inequality due to differences in digital capabilities between countries is gradually worsening. Under these circumstances, the international community's interest in the case of Korea's response to COVID-19 using digital technologies such as information and communications technology (ICT) and artificial intelligence (AI) has increased. Korea has been responding to COVID-19 through a social distancing system using digital technology, a 3T (Test, Trace, Treat) response system based on innovative technology, and measures to contain the spread through the use of data.

In July 2021, the Korean government announced the "Korean version of the New Deal 2.0". The Korean version of the New Deal is a national development strategy tailored to new demands and changes in circumstances to overcome the crisis and lead the global economy in the face of the worst economic downturn and job shock caused by COVID-19. It is a strategy to support with the 'Digital New Deal' to spread dynamism and the 'Green New Deal' for transition to an eco-friendly economy, and 'Strengthening the Safety Net' to protect the vulnerable. Among them, the 'Digital New Deal' is a strategy of developing a data economy based on the ICT industry, which Korea has considerable strengths in. The 'Digital New Deal' strengthens the DNA (Data-Network-AI) ecosystem for digital innovation in all industries, and spreads digital convergence and convergence to various fields to foster new hyper-connected industries such as the metaverse, cloud, and block chain, education, medical care, etc. It is promoted with the task of expanding the 
achievements that can be felt by the people in real life, including the advancement of digital infrastructure such as small to medium enterprises (SMEs) and the spread of digitalization of small and medium-sized businesses.

The spread of COVID-19 around the world is creating various global challenges, and the gap between countries is also widening. At this point, the urgency of global solidarity and international cooperation is being emphasized due to global challenges such as the global spread of infectious diseases, climate change and natural disasters. The rise in the poverty rate due to COVID-19 and the widening development gap between countries is exacerbating the relative poverty level. Emerging countries have an opportunity to enter middle-income countries, while conflict-vulnerable countries are experiencing an increase in refugees.

Korea's 3rd Comprehensive Basic Plan for International Development Cooperation has a vision to realize global values and win-win national interests through cooperation and solidarity in consideration of this global situation. Among them, the 'Promotion of Innovative Official Development Aid (ODA)' was mapped as a strategic goal. In order to bridge the gap between countries, it is necessary to promote innovative ODA, which can be realized in the following ways. Partner countries can strengthen their innovation capabilities by supporting science and technology innovation, bridging the digital divide, promoting the ODA related to the 'Digital New Deal', and supporting public administration innovation. In addition, the innovation of ODA programs must be achieved through the development of the innovative business models, advanced methods for supporting the projects, and new contents. The importance of digital technology is being emphasized in the entire process of international development cooperation.

At this point, this report intends to examine the role of digital technology in achieving the Sustainable Development Goals (SDGs), a key agenda for international development cooperation, through the examples of international organizations and donors.

\section{DIGITAL TECHNOLOGY AND THE SDGS}

Katz and Callorda (2018) presented the relationship between digital technology and the economy through ICT penetration rate and economic growth rate. When 
ICT dissemination in a country exceeds a certain level (minimum threshold) for a leap forward, economic growth occurs. The growth rate will appear as a positive relationship with the increase in the ICT penetration rate. However, after passing the saturation point, the pace of economic growth due to the spread of ICT slows down.

Meanwhile, International Telecommunications Union (ITU) introduced the results of analysis on the impact of wired and wireless broadband penetration and digitization on the gross domestic product (GDP) growth in 2018. The effect of a $1 \%$ increase in each variable (wired, wireless, digitization) on national GDP was as follows: wireless broadband (0.15022), digitization (0.13310), and wired broadband (0.07715), respectively. The impact is also mentioned.

In this report, the correlation between digital technology and the SDGs will be explored through the examples of ITU, SDG Academy, and Huawei.

\section{International Telecommunications Union (ITU)}

Looking at the final document of the SDGs adopted by the United Nations in 2015, the spread of ICT and global interconnection has potential to promote human progress, bridge the gap of digital divide, and provide a huge boost to the development of a knowledge society. In addition, ICT is expected to play a key catalyst role in promoting economic development, social inclusion, and environmental protection, which are the three pillars of sustainable development.

The ITU is an ICT specialized organization under the United Nations that develops and disseminates rules and standards for wired and wireless communications, radio waves, broadcasting, and satellite frequencies, and conducts international coordination and cooperation activities. To maximize the impact of digital technologies on global development, the ITU argues that it can be achieved through new ways of cooperation and the integration of efforts and resources among various stakeholders.

The ITU is working with the Digital Impact Alliance (DIAL) to carry out the "Mainstreaming ICT for SDG" project, which provides the necessary guidelines for decision makers and donors investing in ICT to solve existing problems in achieving the SDG targets. In particular, a whole-of-government approach is necessary for 
the scale of ICT investment to have an impact while emphasizing the importance of building a strong strategic foundation for integrated digital transformation, horizontally and vertically, across the government.

In addition, the ITU is promoting the campaign of "\#ICT4SDG", judging that ICT is the foundation of today's digital economy and has infinite potential for the rapid achievement of SDGs and the ultimate development of people's lives. The role of ICT in achieving the 17 goals of the SDGs is presented through concrete

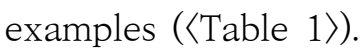

\section{SDG Academy}

The Sustainable Development Solutions Network (SDSN), an advisory body of the $\mathrm{UN}$, is a global network of experts who study the problems and solutions related to the UN's sustainable development. Founded in 2012 with the support of the UN Secretary-General, the SDSN is conducting various projects to research and promote the implementation of the SDGs.

The SDG Academy is a representative education platform of the SDSN, a global initiative of the UN. The SDG Academy creates and selects free, open educational materials on sustainable development and provides them as a global public good. The educational contents of the SDG Academy cover the main issues related to the 17 SDGs and a variety of interdisciplinary topics. The SDG Academy creates and administers (graduate-level) courses on sustainable development for learners worldwide. From solving urban problems to human rights issues and climate change, each course addresses the fundamental issues facing our world today.

Among the 34 training courses of the SDG Academy, there is content labeled 'Tech for Good: The Role of ICT in Achieving the SDGs'. The course, consisting of a total of 10 topics, was developed by UNESCO and the Regional Center for Research on Information Society Development (Cetic.br/NIC.br) of the Brazil Network Information Center. This course brings together people from the fields of ICT and sustainable development to show how digital technologies are empowering billions of people around the world by providing access to education, healthcare, banking and government services. It also shows how big data is being used to inform smarter, evidence-based policies to fundamentally improve people's lives. 


\section{〈Table 1〉 Relationship between SDGs and ICT}

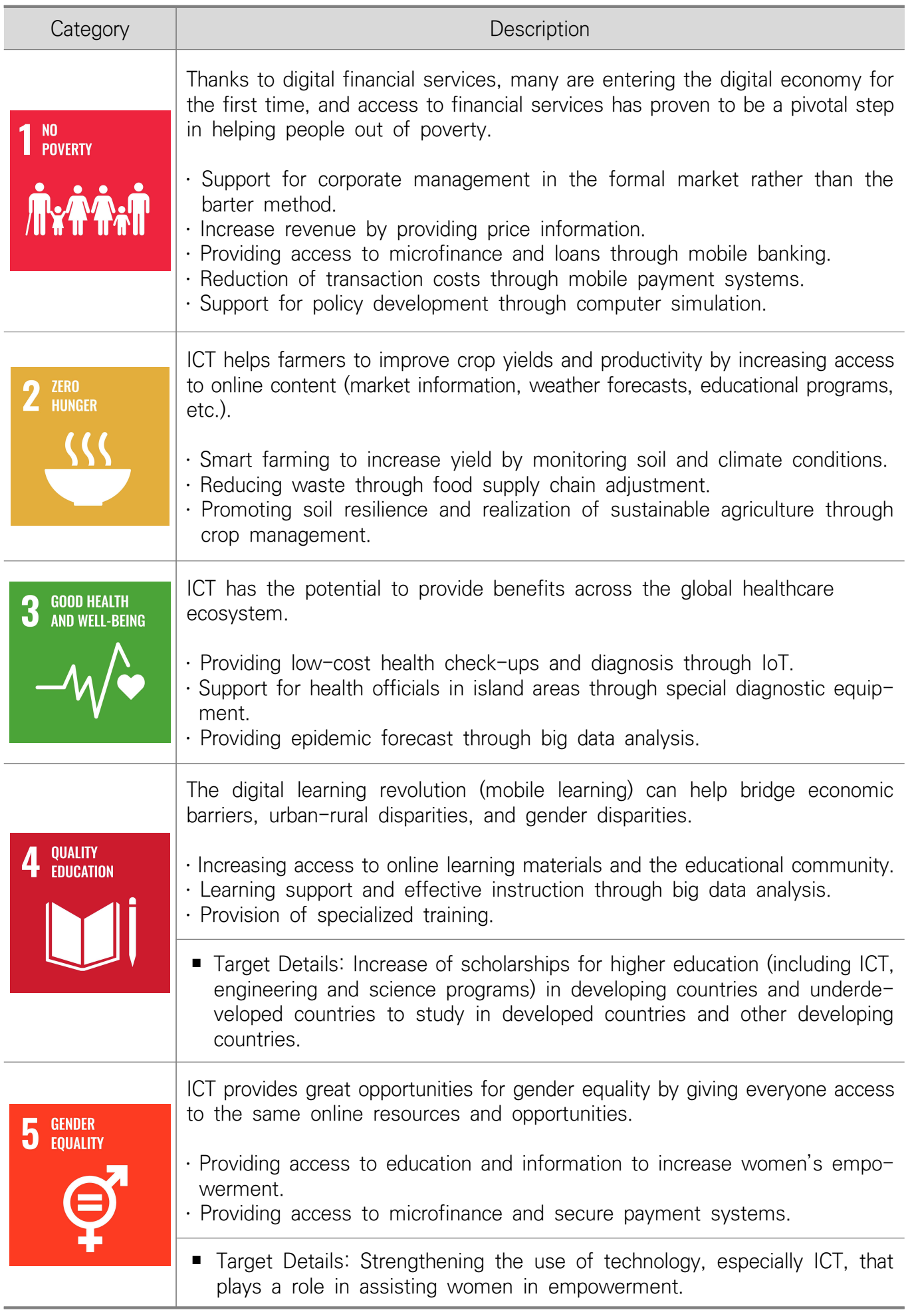




\begin{tabular}{|c|c|}
\hline Cate & Description \\
\hline $6^{\circ}$ & $\begin{array}{l}\text { Contribution to ensuring fair and sustainable expansion of services through } \\
\text { smart water management (supply measurement, monitoring, etc.) using ICT. } \\
\text { - Reducing losses through smart water management. } \\
\text { - Improving the safety through water quality supervision. } \\
\text { - Reducing the risk of contamination through smart water management. }\end{array}$ \\
\hline & $\begin{array}{l}\text { Green technologies and processes using ICT have the potential to play an } \\
\text { important role in significantly reducing global greenhouse gas emissions. } \\
\text { - Management of energy use through smart meters and devices. } \\
\text { - Reducing carbon dioxide emissions and creating a sustainable energy supply } \\
\text { through the use of micro grids and smart grids. }\end{array}$ \\
\hline $8^{0}$ & $\begin{array}{l}\text { ICT itself is changing the way business is done in all areas and creating new } \\
\text { employment opportunities. } \\
\text { - Reducing raw material and carbon dioxide emissions required for the pro- } \\
\text { duction process and increasing productivity through the use of loT and Al. } \\
\text { Small-scale customer-centric manufacturing processes through additive ma- } \\
\text { nufacturing. }\end{array}$ \\
\hline \multirow{3}{*}{9 ANDUSTRY, NNOVATION } & $\begin{array}{l}\text { Emphasizing the importance of establishing a communication network system } \\
\text { (digital infrastructure) to promote the development of scalable solutions for all } \\
\text { SDGs. }\end{array}$ \\
\hline & $\begin{array}{l}\text { - Implementation of smart infrastructure through ICT, IOT, big data, and Al. } \\
\text { - Promoting resilience through preventative maintenance and continuous over- } \\
\text { sight. } \\
\text { - Promoting learning through the plasticity of advanced ICT. } \\
\text { - Rapid prototyping and continuous innovation. }\end{array}$ \\
\hline & - Target Details: Increasing access to ICT technology. \\
\hline 10 & $\begin{array}{l}\text { ICT helps reduce inequality within and between countries by increasing access } \\
\text { to information and knowledge for disadvantaged groups in society (women, } \\
\text { girls, persons with disabilities, etc.). } \\
\text { - Reducing income inequality between countries by decentralizing and localizing } \\
\text { production through the use of ICT. } \\
\text { Reducing inequality among individuals in a country by improving education } \\
\text { through the use of ICT. }\end{array}$ \\
\hline 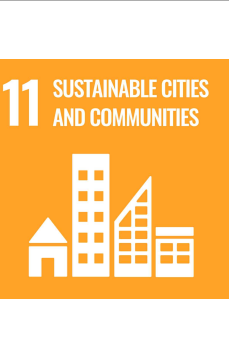 & $\begin{array}{l}\text { ICT provides innovative approaches for more effective and holistic manage- } \\
\text { ment of cities through applications such as smart buildings, smart water } \\
\text { management, intelligent transport systems (ITS) and new efficiencies for } \\
\text { energy consumption and waste management. } \\
\text { - Smart energy-efficient city operation through loT. } \\
\text { - Improvement of urban transportation system through big data analysis and } \\
\text { Al. } \\
\text { - Creating safe residential areas and responsible city government. }\end{array}$ \\
\hline
\end{tabular}




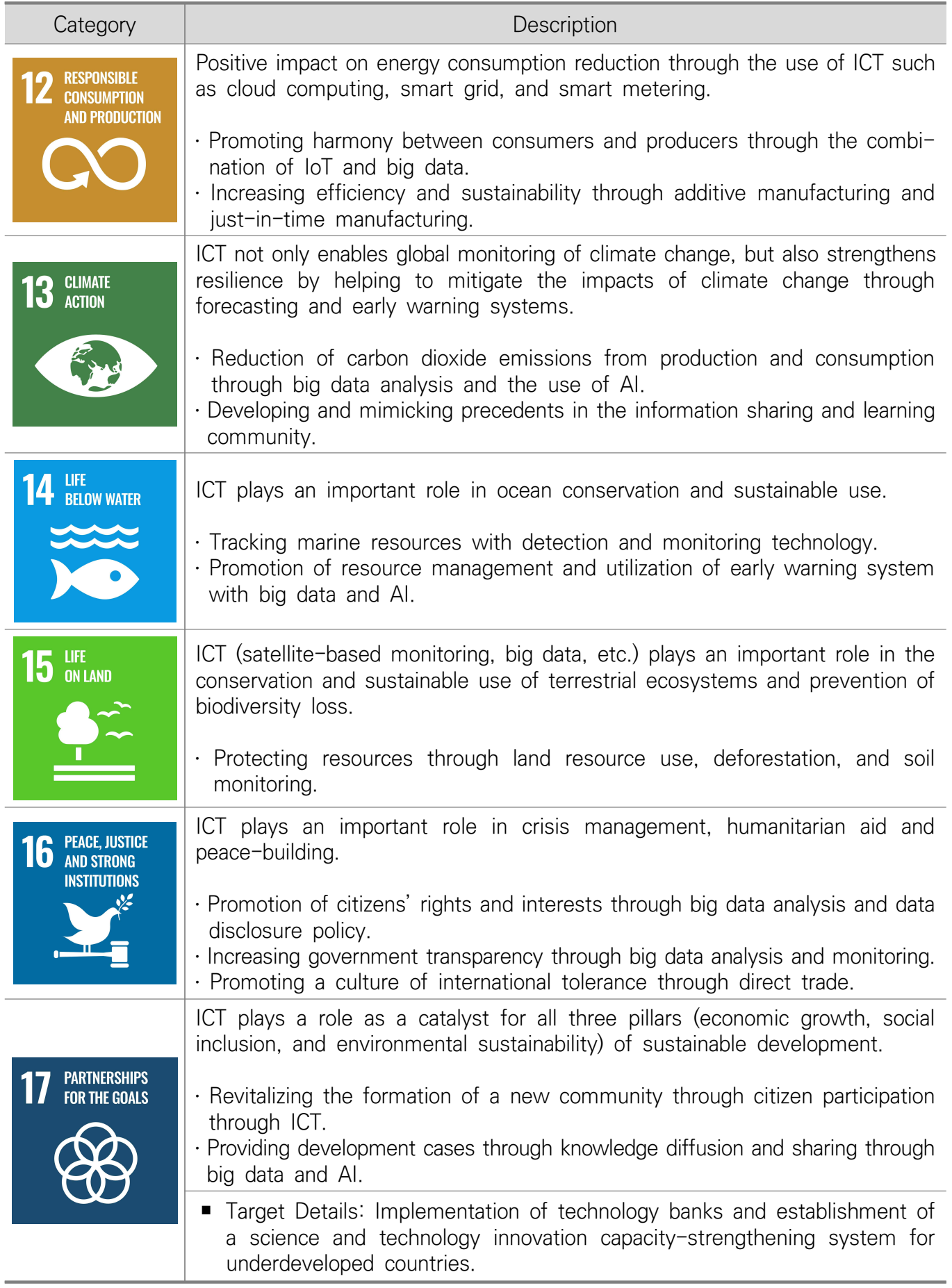

Source: ITU (2021) \& KISDI (2018).

Note: SDG, Sustainable Development Goals; ICT, Information and Communications Technology; Al, Artificial Intelligence; ITU, International Telecommunications Union. 
In addition, it addresses new issues such as privacy, data management, risks to cybersecurity, e-waste, and widening social disparities. Ultimately, the course looks at how stakeholders are coming together to answer the big question about what our future will look like in a hyper-digitized world (〈Table 2$\rangle)$.

\section{Huawei}

Huawei, China's leading electronics and telecommunication equipment manufacturing company, annually reports on the 'ICT Sustainable Development Goals

\section{〈Table 2〉 Syllabus for 'Tech for good: The role of ICT in achieving the SDGs'}

\begin{tabular}{|c|c|}
\hline Module & Main contents \\
\hline $\begin{array}{l}\text { Module } 1 . \\
\text { Welcome to the } \\
\text { digital age }\end{array}$ & $\begin{array}{l}\text { - Bridging the digital divide } \\
\text { - Three approaches to ICT for the SDGs }\end{array}$ \\
\hline $\begin{array}{c}\text { Module } 2 \text {. } \\
\text { Technology for } \\
\text { governments and } \\
\text { citizens }\end{array}$ & $\begin{array}{l}\text { - Equity and access to services } \\
\text { - User-driven public administration } \\
\text { - It's all about the data } \\
\text { - The open government approach } \\
\text { - Case study: Aadhaar in India } \\
\text { - The challenges of digital government }\end{array}$ \\
\hline $\begin{array}{l}\text { Module } 3 . \\
\text { ICT infrastructure }\end{array}$ & $\begin{array}{l}\text { - Enabling ICT: The role of infrastructure } \\
\text { - Promoting digital inclusivity } \\
\text { - Innovations in infrastructure } \\
\text { - Building smart sustainable cities } \\
\text { - ICT as infrastructure: A look at societal platforms }\end{array}$ \\
\hline $\begin{array}{l}\text { Module } 4 . \\
\text { ICT innovations } \\
\text { in health }\end{array}$ & $\begin{array}{l}\text { - Achieving universal health coverage } \\
\text { - Improving healthcare delivery } \\
\text { - Involving the community } \\
\text { - Evidence in action: Success stories of ICT and health } \\
\text { - Emerging challenges and opportunities }\end{array}$ \\
\hline $\begin{array}{l}\text { Module } 5 . \\
\text { Learning in knowledge } \\
\text { societies }\end{array}$ & $\begin{array}{l}\text { - The ecosystem of ict for education } \\
\text { - Education for a connected world } \\
\text { - Sharing knowledge: ICT, openness, and inclusion } \\
\text { - Measuring ICT and education: Frameworks } \\
\text { - Measuring ICT and education: Data and indicators } \\
\text { - Rethinking ICT for education policies }\end{array}$ \\
\hline $\begin{array}{l}\text { Module } 6 . \\
\text { Promoting financial } \\
\text { inclusion }\end{array}$ & $\begin{array}{l}\text { - An introduction to financial services } \\
\text { - The potential of digital platforms } \\
\text { - Mobile payments for marginalized communities } \\
\text { - ICT for enabling access to credit } \\
\text { - Replacing the cash economy } \\
\text { - The challenges of ICT-enabled financial inclusion }\end{array}$ \\
\hline
\end{tabular}




\begin{tabular}{|c|c|}
\hline Module & Main contents \\
\hline $\begin{array}{l}\text { Module } 7 . \\
\text { Measurement and } \\
\text { metrics }\end{array}$ & $\begin{array}{l}\text { - Managing data for the SDGs } \\
\text { - ICT Innovation for statistical development } \\
\text { - Engaging with data: Communications and citizen empowerment } \\
\text { - Case Study: Brazil's Cetic.br } \\
\text { - Measuring ICT } \\
\text { - ICT for monitoring the SDGs } \\
\text { - Limitations of ICT for monitoring the SDGs }\end{array}$ \\
\hline $\begin{array}{c}\text { Module } 8 . \\
\text { Artificial intelligence }\end{array}$ & $\begin{array}{l}\text { - An introduction to artificial intelligence } \\
\text { - Who drives the agenda on "Al for Good"? } \\
\text { - Implications for discrimination and exclusion } \\
\text { - The human side of Al: Risks and ethics }\end{array}$ \\
\hline $\begin{array}{l}\text { Module } 9 \text {. } \\
\text { Concerns for } \\
\text { our digital future }\end{array}$ & $\begin{array}{l}\text { - Privacy and the importance of trust } \\
\text { - Knowing your data rights } \\
\text { - Cybersecurity } \\
\text { - Combatting disinformation } \\
\text { - The downsides of digital }\end{array}$ \\
\hline $\begin{array}{l}\text { Module } 10 \text {. } \\
\text { The way forward }\end{array}$ & $\begin{array}{l}\text { - The New Work force: Six Points about the future of work } \\
\text { - The meaning of work in the digital era } \\
\text { - The open movement } \\
\text { - Closing thoughts on ICT for the SDGs }\end{array}$ \\
\hline
\end{tabular}

Source: SDG Academy Web page (2021).

Note: ICT, Information and Communications Technology; SDG, Sustainable Development Goals; Al, Artificial Intelligence.

Benchmark', which SDG goals have a high potential to be highly related to ICT, and the possibility of achieving those goals by 2030 with the support of ICT.

According to Huawei (2019), it is analyzed that the fields with the highest correlation with ICT are education (SDG 4), health (SDG 3), infrastructure (SDG9), and gender (SDG 5) (〈Figure 1〉).

Meanwhile, Huawei (2019) presents the most important role of ICT in leading sustainable development in three aspects. First, the connectivity provided by ICT infrastructure and the availability of devices such as mobile phones, tablets and computers, play an important role in enabling access to information and services. It provides a basis for development in one way or another for all SDGs, affecting both individuals and organizations in developed and developing countries. Thus, unequal access to all kinds of resources, information, education and services exacerbates that gap globally. 


\section{Where can ICT make the most difference?}

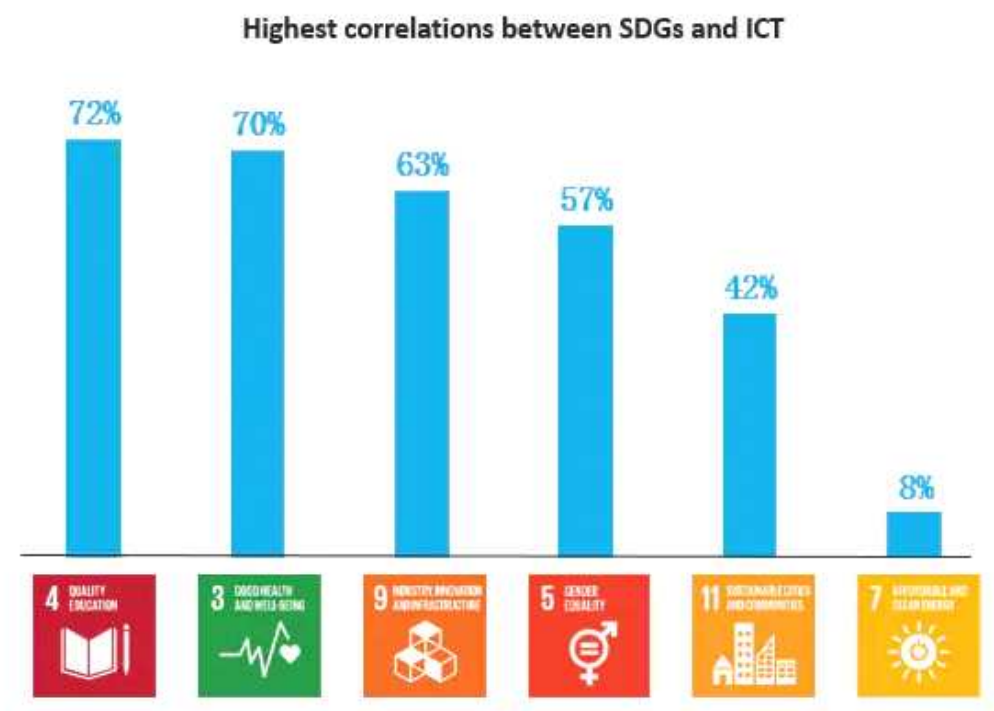

\section{HIGHEST POTENTIAL}

Source: Huawei (2019)

Note: SDG, Sustainable Development Goals; ICT, Information and Communications Technology.

Second, improved accessibility leads to instant or near-instantaneous speed of connectivity and communication between people, homes, intelligent devices, IoT nodes, and the companies and organizations with which people interact. This can increase productivity and innovation across a wide range of sectors and communities, and provide the real-time communication needed to rapidly scale critical human-centric services.

Finally, access to information and communications provided by ICT has tremendous potential to increase the productivity and efficiency of many human activities. Digital technologies provide solutions for more efficient ways to collect and analyze large data sets with the help of big data analytics tools that have far-reaching implications for SDG progress. 


\section{INTERNATIONAL COMMUNITY'S EFFORTS}

As discussed in the previous chapter, ICT plays a major role in achieving the SDGs, and its role is expected to increase in the future. The international community is making various efforts to achieve SDGs through ICT. Multilateral donors and donor countries recognize the importance of ICT in achieving the SDGs and are seeking concrete implementation measures to close the digital divide between developed and developing countries.

\section{Multilateral Donors}

\section{1) International Telecommunications Union (ITU)}

The SDG Mapping Tool was developed to show, through comprehensive visuals, how ITU activities contribute to the SDGs. ITU has identified the relationship between the SDGs and the ITU objectives (Strategic Framework, Connect 2020) and the Action Lines of the World Summit on the Information Society (WSIS).

The mapping work directly links the SDGs and WSIS Action Plans designated to continue strengthening the impact of ICT for sustainable development. All ITU activities are planned, implemented, and evaluated in connection with the achievement of the SDGs (〈Figure 2$\rangle$ ).

\section{〈Figure 2〉 Example of using the SDG mapping tool}

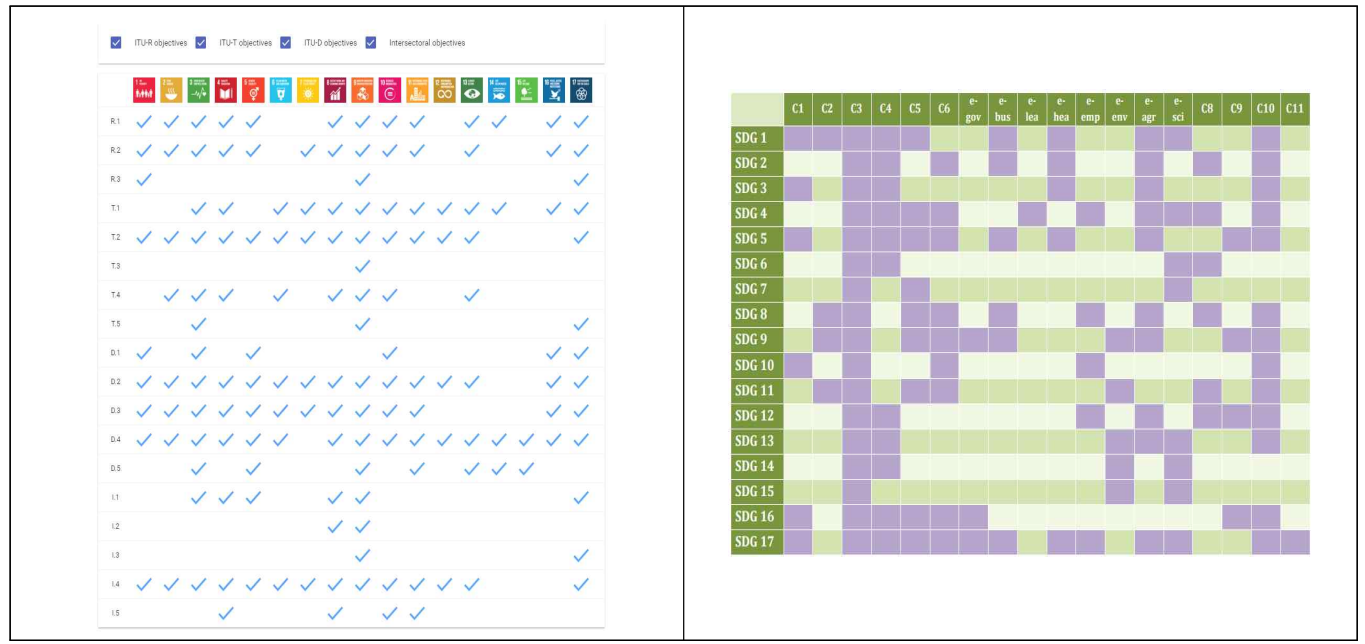

Source: SDG Mapping Tool Web page (2021).

Note: SDG, Sustainable Development Goals; ITU, International Telecommunications Union. 


\section{2) World Bank (WB)}

The WB has been actively promoting the achievement of SDGs through digital technology, starting with the "World Development Report 2016: Digital Dividends" report and the establishment of the "Digital Development Partnership (DDP)" in 2016.

The report "World Development Report 2016: Digital Dividends" points out that while digital technologies are spreading rapidly around the world, they are not bridging the gap in digital dividends, i.e., the wide range of benefits that digital technologies can provide. The WB believes that digital technologies have spurred growth, expanded opportunities and improved service delivery, but the impact of digital technologies is unevenly distributed, and the digital divide, particularly the gap in Internet access, must be bridged for anyone and anywhere.

Meanwhile, the WB predicts the impact and effect of digital technology development on the global economy and each country in the future through the 'Digital Development Partnership (DDP)', and continuously observes and analyzes the changes and side effects occurring around the international community. It also provides a platform that can support technology development and infrastructure construction related to the digital revolution. The platform will bring together public and private sector partners to promote support for developing countries in shaping and implementing digital development strategies and initiatives.

The WB emphasizes that the following areas should be prioritized for effective implementation of digital technology-based projects in developing countries:

- Utilization of data and indices for development projects

- Development of the digital economy environment

- Cyber security

- Generalization of the internet

- Establishment of e-Government

- Establishment of digital service platform

\section{3) Asia Development Bank (ADB)}

With the announcement of 'Strategy 2030' in 2018, ADB began to put the importance of digital technology to the fore to achieve the SDGs. 'Strategy 2030' 
suggests a direction for $\mathrm{ADB}$ to effectively respond to the changing needs of the Asia-Pacific region, and proposes that $\mathrm{ADB}$ should go for the prosperous, inclusive, resilient, and sustainable Asia and Pacific through the strategy.

$\mathrm{ADB}$ pointed out that technological advances in various fields are significantly changing the way goods and services are produced, distributed, delivered and consumed, and also emphasized that these innovative technologies are important principles that can lead new industries and improve people's lives.

$\mathrm{ADB}$ has prepared seven strategies to achieve this vision ( $\langle$ Table 3$\rangle$ ).

\section{〈Table 3〉 7 Strategies to achieve 'Strategy 2030'}

\begin{tabular}{|c|c|c|}
\hline Order & Agenda & Main contents \\
\hline 1 & $\begin{array}{l}\text { Resolving remaining } \\
\text { poverty and reducing } \\
\text { inequality }\end{array}$ & $\begin{array}{l}\text { - Creating decent jobs for human development and social } \\
\text { cohesion. } \\
\text { - Building social safety nets (education, training, and health). }\end{array}$ \\
\hline 2 & $\begin{array}{l}\text { Accelerating the process of } \\
\text { gender equality }\end{array}$ & $\begin{array}{l}\text { - Strengthening the power of women and girls to improve } \\
\text { gender equality and actively considering them in the } \\
\text { business process. } \\
\text { - By } 2030,75 \% \text { of all projects will be carried out in the } \\
\text { direction of improving gender equality. }\end{array}$ \\
\hline 3 & $\begin{array}{l}\text { Reinforcing environmental } \\
\text { sustainability by coping with } \\
\text { climate change and building } \\
\text { Resilience to climate and } \\
\text { disasters }\end{array}$ & $\begin{array}{l}\text { By } 2030,75 \% \text { of all projects will be implemented in a } \\
\text { way that can mitigate and adapt to climate change. }\end{array}$ \\
\hline 4 & Creating a livable city & $\begin{array}{l}\text { Creating integrated solutions for building green, compe- } \\
\text { titive, resilient and inclusive cities. }\end{array}$ \\
\hline 5 & $\begin{array}{l}\text { Promoting rural } \\
\text { development and food } \\
\text { security }\end{array}$ & $\begin{array}{l}\text { Supporting efforts for market connection, agricultural pro- } \\
\text { duction and safe food, non-agricultural income increase, } \\
\text { use of advanced technology, smart farming, etc. }\end{array}$ \\
\hline 6 & $\begin{array}{l}\text { Governance and } \\
\text { institutional capacity } \\
\text { building }\end{array}$ & $\begin{array}{l}\text { - Improving governance and creating an environment for } \\
\text { sustainable growth. } \\
\text { - Helping developing countries overcome economic shocks, } \\
\text { provide services and build capacity. }\end{array}$ \\
\hline 7 & $\begin{array}{l}\text { Fostering regional } \\
\text { cooperation and integration }\end{array}$ & $\begin{array}{l}\text { - Enhancing the competitiveness of developing countries by } \\
\text { improving regional connectivity. } \\
\text { - Supporting cooperation to alleviate border issues such as } \\
\text { climate change, pollution, energy and water security, and } \\
\text { disease transmission. }\end{array}$ \\
\hline
\end{tabular}

Source: ADB (2018a).

Note: ADB, Asia Development Bank. 
In line with the establishment of 'Strategy 2030,' ADB presented 'Digital Agenda 2030 ' to provide a vision and roadmap for ADB's digital transformation. The purpose of the initiative is to respond to the demand amongst its clients and partners as well as the organization as a whole for a more modern and connected ICT system.

'Digital Agenda 2030' presents a phased implementation, emphasizing that the first phase builds and optimizes ADB's core ICT system and supports ADB to benefit from rapid digital transformation in the Asia-Pacific region (laying the groundwork for digital transformation). In the subsequent phase, the main content is to further develop digital innovation to increase the integration and connectivity of ICT systems and to improve digital products and services (〈Figure 3$\rangle$ ).

Meanwhile, ADB is discussing development strategies by country, sector, and topic toward the digital economy by holding the 'Digital Development Forum (DDF)'. At the forum held in 2018, discussions took place among members to find ways to maximize promising digital technologies for development in the context of the Fourth Industrial Revolution.

\section{〈Figure 3〉 Programs of the Digital Agenda 2030}

\section{Business Optimization}

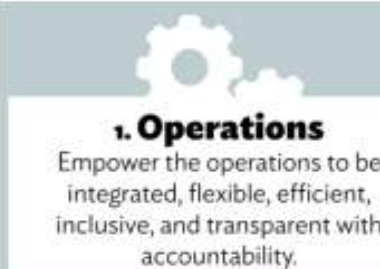

\section{Financial Services}

Enable flexible and innovative

financial products and services.

\section{Administrative and Corporate Services}

Renovate ADB's corporate systems.

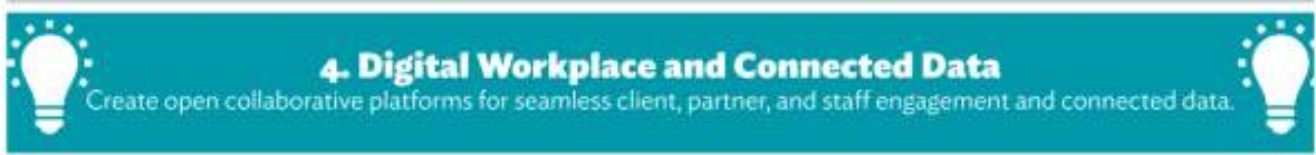

Source: ADB (2018b).

Note: ADB, Asia Development Bank. 


\section{Donor Countries}

\section{1) United States of America: US Agency for International Development}

(USAID)

USAID, which is called the leader in digitalization, announced 'Digital Strategy 2020-2024', which contains an institutional vision for development and humanitarian assistance in the rapidly evolving digital environment in 2020. The strategy emphasizes the creation of an open, secure and inclusive digital ecosystem that can contribute to broad and measurable development and humanitarian outcomes. Through this, it was intended to support the self-reliance of emerging market countries.

USAID has two crucial and interconnected strategic objectives in achieving this digital strategy. The first objective is to improve measurable development and humanitarian outcomes through the responsible use of digital technologies in USAID programs. The second goal is to strengthen the openness, security and inclusion of the national digital ecosystem. Specifically, USAID tried to utilize digital technology throughout development cooperation projects through 'Digital Strategy 2020-2024' and to support partner countries in establishing a sound digital ecosystem by spreading digital best practices. In addition, by establishing an open, stable, and inclusive digital ecosystem, it was intended to strengthen the digital capabilities of the underprivileged and promote development cooperation with various actors such as businesses and civil society.

The focus areas of the 'Digital Strategy 2020-2024' include bridging the gender gap through empowerment of women, cybersecurity, digital healthcare, digital literacy, financial inclusion, innovative technologies, and information sharing. In order to provide effective support in these areas, various related organizations need to have a role and cooperate, and continuous funding must be made.

Data, security, and digital payment systems can be established based on a digital society, and the importance of human resource development in partner countries is emphasized in the process. In addition, emphasizing the importance of developing a government policy framework for bridging the digital divide between countries, national broadband policies, universal services, and public-private cooperation are important means to a digital society (〈Figure 4〉). 
〈Figure 4〉 Tracks for achieving the goals of 'Digital Strategy 2020 2024'

\begin{tabular}{l} 
To achieve the overall goal of the Strategy, these objectives will be executed through four tracks: \\
\hdashline TRACK 1: ADOPT AN ECOSYSTEM APPROACH $>$ Develop tools and resources necessary to deliver \\
the unique opportunities and risks that digital technology presents across USAID's Program Cycle
\end{tabular}

Source: USAID (2020).

Note: USAID, US Agency for International Development.

\section{2) United Kingdom: Foreign, Commonwealth and Development Office (FCDO)1)}

In 2018, the UK published the 'Digital Strategy 2018-2020: Doing Development in a Digital World' to lead the world in an open, modern and innovative approach to development, emphasizing digital technology as the core of its work. A key objective of the 'Digital Strategy 2018-2020' is to make the UK to be a global leader in digital technology and development to make a bigger, faster and more cost-effective impact on the lives of the poor.

Digital technologies have the potential to change the lives of the poor, enable development and prosperity, and accelerate the process towards global goals. However, there are significant barriers to fully realizing the development potential of digital technologies. Not everyone in the world has access to the Internet, and there is a risk of being left behind in the transition to a digital world. The advantages of the Internet also come with new risks such as monopolies, growing inequality, and the use of digital technologies by states and businesses to control the citizens.

The UK intends to implement the following action plans to tackle global poverty and achieve global goals. First, the UK identifies best practices for using digital solutions in aid projects. And through the promotion of common principles and standards for digital development across the aid system, the UK is willing to help

1) In September 2020, the British Foreign and Commonwealth Office (FCO) and the Department for International Development (DFID) merged into the FCDO. 
more digital products and services reach the poor, empower them and improve their lives. It also promotes affordable and secure Internet access in developing countries, enabling everyone to enjoy the benefits of digital technology.

\section{3) Germany: Bundesministerium für wirtschaftlische Zusammenarbeit und Entwicklung (BMZ)}

Germany announced the 'Digital Agenda of the BMZ' in 2018, emphasizing the use of the digital revolution to achieve sustainable development. 'Digital Agenda of the BMZ' contains Germany's operational strategy for modern development cooperation in a world undergoing digital transformation. It explains the contribution of the BMZ to the digital agenda of the German government and provides a framework of guidance for the implementation of digital initiatives.

The 'Digital Agenda of the BMZ' also explains how to capitalize on and address the challenges of digital transformation. Topics covered include climate, agriculture, education, business and economic development, displacement and migration. The five strategic goals of the 'Digital Agenda of the BMZ' include leveraging digital innovation, strengthening democratic processes, helping displaced people, creating future-oriented jobs, protecting human rights and ensuring participation.

Meanwhile, the BMZ is building and collaborating with companies and associations in the EU for digital cooperation, and mainly supports Africa. Major examples include digital center construction (accessibility), mobile payment system construction (economic), online vocational training (education), early response system for infectious diseases, drone-use remote drug supply (health and medical care), and ICT technology application (agriculture).

\section{4) France: Agence Française de Développement (AFD)}

AFD has published the "Towards a World in Common: AFD Group 2018-2022 Strategy' in 2018 to meet the new challenges and goals of international development cooperation (AFD, 2018). This strategic guideline is intended to serve as a platform for accelerating global digital transformation and incorporating digital technology and culture into the mainstream.

Through this strategy, AFD has restructured the six transitions (social and demographics, energy, territory and ecosystems, digital technology, economy and 
finance, and politics and civics) to achieve the SDGs in key areas. Among them, 'Digital and Technological Transition' focuses on digital infrastructure construction, institutional and capacity building support.

AFD aims to promote technologies that provide a French and European vision for the key social, ecological and economic issues (Cyber Security, Net Neutrality, Open Source Software, Privacy, Cultural Diversity and Environmental Protection) brought about by accelerated development cooperation methods, management of the social impacts of the digital revolution, and new digital technologies.

\section{5) Japan: Japan International Cooperation Agency (JICA)}

JICA proposes contributing to the achievement of SDGs through the active use of digital technology, fostering ICT talent, and strengthening the linkage with Japan's domestic ICT policies as basic policies for international development cooperation. In the ICT sector, JICA's development cooperation promotion strategy consists of four elements: improving ICT policy-making ability, developing human resources for ICT support, developing ICT infrastructure, and promoting ICT use and application.

This development strategy was implemented with specific measures such as publicity for ICT and dispatch of experts, support for ICT engineer training, establishment of broadband networks, education, industry promotion and provision of support for ICT use and application in areas such as disaster risk reduction. JICA is currently considering industry-based solutions, business support solutions and incubating solutions to further promote the use and application of digital technologies (〈Table 4〉).

〈Table 4〉 Utilization of digital technology in JICA's international development cooperation

\begin{tabular}{c|c|l}
\hline Order & Agenda & \multicolumn{1}{|c}{ Description } \\
\hline 1 & Industry-based solutions & $\begin{array}{l}\text { Providing ICT services as a package to solve problems in } \\
\text { developing countries by utilizing ICT solutions used in } \\
\text { Japan and other countries. }\end{array}$ \\
\hline 2 & $\begin{array}{c}\text { Solutions for business } \\
\text { activation }\end{array}$ & $\begin{array}{l}\text { Proposal of the use of ICT services as a tool to further } \\
\text { improve the efficiency of existing projects. }\end{array}$ \\
\hline 3 & Solution incubating & $\begin{array}{l}\text { Supporting the establishment of new businesses and } \\
\text { services using ICT in developing countries. }\end{array}$ \\
\hline
\end{tabular}

Source: JICA Web page (2021).

Note: JICA, Japan International Cooperation Agency; ICT, Information and Communications Technology. 
Meanwhile, Japan is actively promoting cooperation in the field of digital technology through cooperation with international organizations. In the field of cyber security, JICA is supporting issues' response and capacity building in the field through a consultative body between the Japanese government and ASEAN member states. Japan is also the largest donor of ADB's Asian Development Fund $(\mathrm{ADF})$, which supports and cooperates actively in the digital technology field.

\section{Cases of Achieving SDGs through Digital Technology}

As such, the international community is making various efforts to achieve the SDGs. From multilateral donors such as ITU, WB, and ADB, to donor countries such as the United States, the United Kingdom, Germany, France and Japan, they are using digital technology to help ensure that no one is left behind (〈Table 5〉).

〈Table 5〉 Status of the use of digital technology by donors in the international community to achieve SDGs

\begin{tabular}{|c|c|c|c|c|c|c|c|c|c|c|}
\hline Category & $\begin{array}{l}\text { Infrast- } \\
\text { ructure }\end{array}$ & $\begin{array}{c}\text { Capa- } \\
\text { city } \\
\text { building }\end{array}$ & $\begin{array}{c}\text { Institu- } \\
\text { tion }\end{array}$ & $\begin{array}{l}\text { Partn- } \\
\text { ership }\end{array}$ & Finance & $\begin{array}{l}\text { Entre- } \\
\text { prene- } \\
\text { urship }\end{array}$ & $\begin{array}{l}\text { Infor- } \\
\text { mation } \\
\text { security }\end{array}$ & Health & Gender & Remark \\
\hline ITU & 0 & 0 & 0 & 0 & & & 0 & & & $\begin{array}{l}\text { Diversity, } \\
\text { main- } \\
\text { stream }\end{array}$ \\
\hline WB & 0 & 0 & & 0 & $\bullet$ & $\bullet$ & 0 & 0 & & Data \\
\hline$A D B$ & 0 & 0 & 0 & & 0 & & & & & \\
\hline US & & 0 & & 0 & 0 & 0 & 0 & 0 & 0 & \\
\hline UK & 0 & & & 0 & & 0 & 0 & 0 & & Data \\
\hline Germany & & & & 0 & & 0 & & & & $\begin{array}{l}\text { Human } \\
\text { rights }\end{array}$ \\
\hline France & 0 & 0 & 0 & & & & 0 & & & $\begin{array}{l}\text { Diversity, } \\
\text { climate } \\
\text { change }\end{array}$ \\
\hline Japan & 0 & 0 & & & & 0 & & & 0 & $\begin{array}{l}\text { Main- } \\
\text { stream }\end{array}$ \\
\hline
\end{tabular}

Note: SDG, Sustainable Development Goals; ITU, International Telecommunications Union; WB, World Bank; ADB, Asia Development Bank. 
Meanwhile, in 2019, the United Nations Conference on Trade and Development (UNCTAD) introduced major examples by linking the efforts of the international community with the detailed goals of SDGs.

First, the WB's 'Identification for Development (ID4D)' case was introduced as a best practice for achieving the end of poverty in all its forms everywhere (SDG 1), and through this initiative, an inclusive and reliable digital ID system was established. Thus, the foundation environment was created to provide economic opportunities to the most vulnerable.

The best practice to end hunger, achieve food security, achieve improved nutrition and achieve sustainable agriculture (SDG 2) is the FAO and ITU's '\#HackAgainstHunger'. The project supports the transformation of young entrepreneurs' ideas into real impact by providing incubation and acceleration on innovative technology-based solutions that can contribute to ending hunger and achieving food security.

A good example of achieving healthy lives and promoting well-being for all ages (SDG 3) is the project of 'Kasha - Improving women's health in Rwanda (online platform)' implemented by the UK and Unliever. This project helped to overcome the problem of social stigma by allowing women to purchase the hygiene products they need online.

Achieving inclusive and equitable quality education and promoting lifelong learning opportunities for all (SDG 4) can be seen through Finland's 'ICT Education in Vietnam' project. This project promoted the connection between education and employment of students who completed higher education in the field of ICT.

A good example of achieving gender equality and the empowerment of all women and girls (SDG 5) can be seen in Finland's 'Digital Challenge 3rd edition - Innovation for Women in Africa'. This was supported by providing rewards to startups that contribute to improving gender equality and treatment of women in Africa.

A good example for achieving sustainable management and availability of water and sanitation for all (SDG 6) is Germany's 'MajiData - Database for Clean Water in Kenya to create'. Through this project, Germany supported the gradual improvement of water and sanitation services through increased transparency in Kenya's urban, low-income areas. 
Best practices in achieving guaranteed access to affordable, reliable, sustainable and modern energy for all (SDG 7) can be found in the project of the AfDB, the WB, Sweden and the United States' 'Power Africa to Create'. The project doubled access to electricity in Africa over the next decade.

A good example of achieving the goals of sustainable, inclusive and sustainable economic growth, full and productive employment and decent work for all (SDG 8) is the project of the 'Decent Work for Youth using ICT' which was implemented by the EU and Germany. Through the project, the two donors strengthened the professional competence of young people in ICT-related occupations.

A good example of building resilient infrastructure, promoting inclusive and sustainable industrialization and achieving innovation (SDG 9) can be found in the project of 'The Eastern Africa Submarine Cable System', a collaboration between the AfDB, the WB, France and Germany. The project connected traffic from East and South African markets to Europe, Asia and the Americas via submarine cables.

An exemplary case for achieving domestic and inter-country inequality reduction (SDG 10) is Germany's 'Mobile communication for rural areas in India'. Through the project, Germany supported the construction of a wireless communication mast in the remote villages of India.

Best practices for achieving inclusive, safe, resilient and sustainable cities and dwellings (SDG 11) can be found in the project of 'Youthmappers (Nigeria)' implemented by the WB and the US. The project identified illegal waste dumping sites through GPS and photographic images, and provided a solution for urban waste.

Achieving guarantees of sustainable consumption and production modalities (SDG 12) is an example of the ITU's 'Support to e-Waste Management in Malawi'. Through the project, ITU supported the establishment of a policy and regulatory system such as a national strategy and action plan for e-waste management in Malawi.

Best practices for achieving an emergency response to combat climate change and its impacts (SDG 13) can be found in the Global System for Mobile communications Association (GSMA) and the UK's 'Mobile for Humanitarian Innovation'. Through this initiative, the UK and the GSMA have supported innovative solutions and partnerships in areas such as digital identity, mobile money, mobile-based energy, resilience to climate change and food security. 
A good example of the conservation and sustainable use of oceans, seas and marine resources for sustainable development (SDG 14) is the UK's 'Global Challenges Research Fund, International Partnership Programme'. Through this project, the UK supported the enhancement of the sustainability of Indonesian fisheries, improvement of livelihood stability for fishermen, reduction of safety issues through improved connection lines, and reduction of environmentally destructive fishing methods.

An exemplary case for protecting, restoring and promoting sustainable use of terrestrial ecosystems, sustainably managing forests, combating desertification, restoring cessation of land degradation, and achieving cessation of biodiversity loss (SDG 15) is Finland's 'Development of Management Information System for Forestry Sector in Vietnam'. Finland has supported Vietnam's forest resources management based on the latest information and poverty reduction measures in a sustainable way.

Meanwhile, UNCTAD's 'Automated Systems for Customs Data in 100 Developing Countries' is an example of promoting a peaceful and inclusive society for sustainable development, ensuring justice for all and achieving effective, accountable and inclusive institutions at all levels (SDG 16). The project improved and facilitated trade and customs procedures through automation, increased transparency and efficiency, and helped increase government customs revenues.

Finally, an exemplary case of strengthening the means of implementation and achieving the revitalization of global partnerships for sustainable development (SDG 17) can be found in Canada and the United Kingdom's project of the 'Information \& Networks in Asia and Sub-Saharan Africa'. The project supported the production and sharing of high-quality, credible evidence of the impact of digital initiatives in the fields of governance, science, learning and entrepreneurship.

\section{THE WAY FORWARD}

This study examines the role of digital technology in achieving the SDGs through examples of international organizations and major donors. The directions of development cooperation in the field of digital technology that can be derived through case analysis are presented as follows, with contents that everyone can 
agree on at a certain level.

First, the vital task is to create a foundation environment for the realization of a digital ecosystem. In addition, regulations and systems need to be prepared so that the established digital environment can function properly, and national capabilities must be strengthened by enhancing digital literacy through education and developing high-quality human resources. Meanwhile, cooperation with various stakeholders is essential to respond to global challenges and trans-border issues. As entrepreneurship and innovation are required to strengthen the digital value chain, the focus should be on collaboration with the private sector.

In addition, it is necessary to apply ICT in all areas of development cooperation (Public Administration, Transportation, Education, Health and Sanitation, Energy, etc.), and to strengthen the planning and implementation of donor activities in consideration of the 17 goals of the SDGs continuously. In particular, considering the level of correlation between digital technology and the SDGs, it can be suggested to reinforce cooperation in sectors (Education, Health, Gender, etc.) that can perform better.

While COVID-19 has created an opportunity to accelerate the trend of transition to the digital economy in the international community, the support for datadriven digital solutions (Cloud, Internet of Things, AI, Information Security, etc.) is being emphasized in the field of development cooperation.

However, the core to proposing through this report is to build an open and secure universe for realizing and implementing all these suggestions. Given the relationship (threshold) between digital penetration and economic growth, some level of infrastructure is essential. In particular, it is important to establish an open and secure broadband network environment, and the principle of the support strategy is to promote private investment along with ODA support for partner countries.

In addition, it is necessary to consider how cooperation in the digital technology field can strengthen the digital value chain in the future. While looking at the development cooperation for digital technology based on Korea's ICT integrated classification system ${ }^{2}$, it can be seen that the focus is on corresponding to the

2) In order to systematize the comprehensive scope of ICT statistics and to reconcile the conflicts between statistics, in 2017 MSIT decided to establish an integrated classification system for Korea's existing ICT statistics (18) and established the ICT statistical classification system. 
equipment of ICT, software and digital contents. Considering that the key to building a digital ecosystem lies in strengthening the value chain, it is required to carefully consider the elements of the services of ICT in the process of cooperation.

\section{REFERENCES}

Agence Française de Développement. (2018). Towards a world in common: AFD group 2018 2022 strategy. Berlin, Germany: AFD.

Asia Development Bank. (2018a). Digital agenda 2030: Special capital expenditure requirements for 2019 2023. Mandaluyong, Philippines: ADB.

Asia Development Bank. (2018b). Strategy 2030: Achieving a prosperous, inclusive, resilient, and sustainable Asia and the Pacific. Mandaluyong, Philippines: ADB. Huawei. (2019). ICT sustainable development goals benchmark. Shenzhen, China: Huawei.

International Telecommunications Union (ITU). (2018). The economic contribution of broadband, digitization and ICT regulation. Geneva, Swiss: ITU.

International Telecommunications Union (ITU). (2020). How broadband, digitization and ICT regulation impact the global economy. Geneva, Swiss: ITU.

International Telecommunications Union (ITU). (2021). Pandemic in the Internet age: From second wave to new normal, recovery, adaptation and resilience. Geneva, Swiss: ITU.

International Telecommunications Union \& United Nations Educational, Scientific and Cultural Organization. (2020). The state of broadband 2020: Tackling digital inequalities/a decade for action (UIT/UNESCO broadband commission for sustainable development). Geneva, Swiss: ITU.

Katz, R., \& Callorda, F. (2018). Accelerating the development of Latin American digital ecosystem and implications for broadband policy. Telecommunications Policy, 42(9), 661-681.

Korea Information Society Development. (2018). A Study on International Cooperation of ICT for Achieving SDGs in the Asia-Pacific Region. Seoul, Korea: KISDI. United Nations. (2020). SDG academy: Annual report 2020. New York, NY: UN. United Nations Conference on Trade and Development. (2019a). Digital economy 
report 2019: Value creation and capture, implications for developing countries. New York NY: UN.

United Nations Conference on Trade and Development. (2019b). Donor support to the digital economy in developing countries: A 2018 survey of public and private organizations. Geneva, Swiss: UNCTAD.

US Agency for International Development. (2020). Digital strategy 2020-2024.

Washington, DC: USAID. 